\title{
Stability of crack propagation during bending tests on brittle materials
}

\author{
(Estabilidade de propagação de trinca durante testes de \\ flexão em materiais frágeis)
}

\author{
C. M. Peret, J. A. Rodrigues \\ Materials Microstructural Design Group - GEMM, Department of Materials Engineering - DEMa \\ Federal University of S. Carlos - UFSCar, Via Washington Luiz, km 235, S. Carlos, SP, Brazil 13565-905 \\ josear@ufscar.br
}

\begin{abstract}
Applications of ceramic materials usually involve thermal stresses that can reduce their lifetime considerably. One of the most relevant mechanical properties for evaluating thermal shock damage resistance is the energy of fracture. In order to obtain this property, a stable crack growth regimen must be achieved throughout the test. In this paper, three-point bending tests are analyzed to determine how machine stiffness influences load point displacement rates. Understanding the differences between recorded and adjusted displacement rates is important in determining the stability of crack growth. This statement is corroborated by experimental data on sintered high-alumina, low-cement refractory castables.
\end{abstract}

Keywords: energy of fracture, stable crack growth, 3-point bending test, refractory castable, stiffness.

\section{Resumo}

Em geral, a aplicação de materiais cerâmicos envolve a ocorrência de tensões térmicas que podem encurtar consideravelmente o seu tempo de operação. Uma das propriedades mecânicas mais relevantes para a avaliação da resistência ao dano por choque térmico é a energia de fratura. Para se obter isso, é necessário que ao longo do teste se atinja uma condição de crescimento estável de trinca. Neste artigo, analisa-se o teste de flexão em três pontos para se determinar como a rigidez da máquina de ensaio influencia a taxa de deslocamento do ponto de aplicação de carga. Para o estabelecimento da estabilidade do crescimento de uma trinca, é importante a compreensão das diferenças entre as taxas de deslocamento registradas e as ajustadas. Esta afirmação é corroborada por dados experimentais obtidos com concretos refratários de alta alumina e baixo cimento.

Palavras-chave: energia de fratura, crescimento estável de trinca, teste de flexão em 3 pontos, concretos refratários, rigidez.

\section{INTRODUCTION}

Energy of fracture $\left(\gamma_{\text {wof }}\right)$ is defined as the average resistance to the propagation of cracks through a material, and many researchers consider it one of the most important properties for forecasting the performance of cracks under thermal shock. In the case of refractory ceramics, this property is considered crucial, since it is impractical to attempt to prevent cracks from propagating through sudden variations of temperature [1-3]. Hence, the design of microstructural features aimed at minimizing thermal shock damage is the only feasible option.

The value of $\gamma_{\text {wof }}$ is measured by the work performed by the testing machine, usually on a single edge notched beam (SENB) or a chevron notched specimen, until a single crack propagates completely. The energy of fracture corresponds to the area under the curve of load, $\mathrm{P}$, versus load point displacement, d, divided by the total projected surface area, A, of the two fracture surfaces formed,

$\gamma_{\mathrm{wof}}=\frac{\int \mathrm{P} \cdot d \mathrm{~d}}{2 \mathrm{~A}}$
The crack propagation must be stable so that an instantaneous readout of load and actuator displacement can be obtained throughout the test. Because the high speed involved in unstable crack propagation exceeds the resolution of the sensors [4], catastrophic propagation would hinder this readout. At the onset of crack propagation, the stored elastic strain energy not only depends on the material's toughness, $\mathrm{K}_{\mathrm{IC}}$, and its Young's modulus, E, but also on geometric factors such as the specimen's dimensions and notch depth and on the stiffness of the testing equipment, including the bending supports [5]. During the fracture process, this potential energy is transformed into surface energy and sometimes dissipated by the interaction of the crack with the microstructure, leading to a rising R-curve behavior. The excess energy contributes for the acceleration of the propagation front. For steady-state propagation to be achieved, the rate of elastic energy released must be always equivalent to that of the energy consumed to form the two fracture surfaces. Optimizing the test parameters (actuator speed, machine stiffness, specimen height, notch depth, etc.) facilitates the achievement of stable crack growth. For this optimization, a theoretical study of how each variable influences the accumulation and release of elastic energy in 
the system specimen-equipment is of great help. This work reports on a study of the real experimental conditions to which a SENB sample is subjected during stable crack propagation under a three-point bending configuration.

\section{STABLE CRACK PROPAGATION}

Stable crack growth is achieved in brittle materials according to the energy stored in the specimen as a result of elastic strain, and to the rate of its release during the formation of fracture surfaces.

In order to reduce the maximum load attained and, therefore, the stored energy at the onset of propagation, a notch is made, which acts as a surface defect, concentrating the stress at its tip. The shape and depth of this notch determine its effectiveness.

For three-and four-point bending test configurations, which can be controlled by the load-point displacement rate, single-edge (SENB) or "chevron" notches can be used. The latter notches are more effective because the breaking area at the beginning of the propagation is small and grows continuously along with the crack [6]. The angle of the tip of the chevron notch is also important for propagation stability: the more acute the angle, the greater the stress concentration. This geometry, however, has the disadvantage of diminishing the total fractured area, thereby reducing the representativeness of the measurement, which could be especially detrimental in the analysis of coarse-grained materials such as refractories.

Nakayama, Abe and Bradt [5] studied three-point bending tests of SENB specimens from the standpoint of crack propagation stability. They considered that the overall stored energy, $U_{T}$, is given by

$$
\mathrm{U}_{\mathrm{T}}=\mathrm{U}_{\mathrm{S}}+\mathrm{U}_{\mathrm{M}}+\mathrm{W}_{\mathrm{fs}}+\mathrm{U}_{\mathrm{k}}
$$

where $U_{\mathrm{S}}$ represents the elastic energy stored in the specimen; $\mathrm{U}_{\mathrm{M}}$, the elastic energy stored in the testing machine; $\mathrm{W}_{\mathrm{fs}}$, the overall work done by the machine; and $U_{k}$, the crack's kinetic energy, which, in a situation of quasi-static propagation, may be neglected. In terms of energy of fracture, $\mathrm{W}_{\mathrm{fs}}$ is equal to the product of $\gamma_{\text {wof }}$ by twice the projected fractured area at the end of the process.

Considering that $\mathrm{U}_{\mathrm{T}}$ is not a function of the crack size, since the energy dissipation is included in the $\mathrm{W}_{\mathrm{fs}}$ term, stable crack growth occurs when the energy release rate equals the energy consumed in the formation of the fracture surfaces,

$$
-\frac{d}{d \mathrm{c}}\left(\mathrm{U}_{\mathrm{S}}+\mathrm{U}_{\mathrm{M}}\right) \leq \frac{d \mathrm{~W}_{\mathrm{fs}}}{d \mathrm{c}}
$$

where $d c$ is the infinitesimal variation of the crack length.

The accumulated elastic energy depends on the system's compliance, represented by the sum of the specimen's compliance, $\lambda_{\mathrm{s}}$, and that of the machine, $\lambda_{\mathrm{M}}$, according to the relation:

$$
\mathrm{U}_{\mathrm{S}}+\mathrm{U}_{\mathrm{M}}=\frac{1}{2} \mathrm{P}^{2}\left(\lambda_{\mathrm{S}}+\lambda_{\mathrm{M}}\right)
$$

where $\mathrm{P}$ is the instantaneous external applied load.

According to Nakayama, Abe and Bradt [5], the compliance of a SENB specimen in the three-point bending geometry is:

$$
\lambda_{\mathrm{S}}=\frac{\mathrm{L}^{3}}{4 \mathrm{Ebh}^{3}}\left[1+2.4 \frac{\mathrm{h}^{2}}{\mathrm{~L}^{2}}(1+v)\right] \frac{3 \mathrm{~L}^{2}}{2 \mathrm{Ebh}^{2}} \cdot \mathrm{Y}(\alpha)
$$

where $\mathrm{b}$ and $\mathrm{h}$ are, respectively, the specimen's width and the height; $\mathrm{L}$ is the lower span; $v$ is Poisson's ratio, and $\mathrm{Y}(\alpha)$ is a geometric corrective factor for the relative depth of the notch, $\alpha$, given by:

$\mathrm{Y}(\alpha)=\frac{\alpha}{1-\alpha}\left(5.58-19.57 \alpha+36.82 \alpha^{2}-34.94 \alpha^{3}+12.77 \alpha^{4}\right)$

where $\alpha$ is defined as $\mathrm{c} / \mathrm{h}$, c being the notch depth or, after the beginning of crack propagation, the crack depth.

Fig. 1 depicts the specimen's compliance as a function of the relative crack depth, for a specified condition, according to Eqs.(E) and (F).

According to Eq.(E), the specimen's compliance is constant up to the onset of propagation, increasing during the crack's growth due to the variation of $Y(\alpha)$ [1].

Replacing specific equations for the specimen's compliance under 3-point bending leads to the following stability criterion [5]:

$$
\frac{\mathrm{h}^{2}}{\mathrm{c}^{2}}\left\{1+\frac{\mathrm{L}}{\mathrm{h}} \cdot\left[1+1.2 \frac{\mathrm{h}^{2} \mathrm{E}}{\mathrm{L}^{2} \mathrm{G}}\right]+\frac{\mathrm{Ebh}^{2} \lambda_{\mathrm{M}}{ }^{3}}{\mathrm{~L}^{2}}\right\} \leq \frac{\gamma_{\text {wof }}}{\gamma_{\text {eff }}}
$$

where $\gamma_{\text {eff }}$ is the effective energy of fracture and G is the shear modulus of the material.

According to Eq.(G), materials with a low Young's

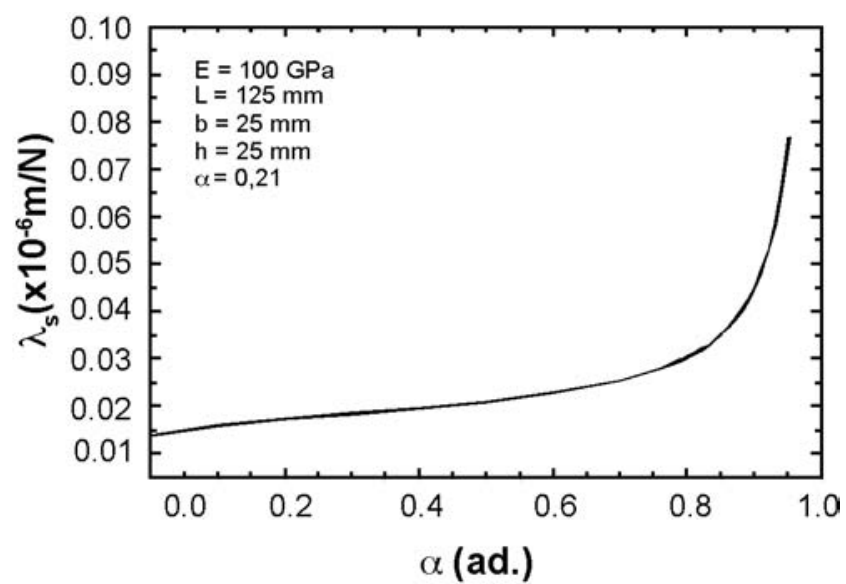

Figure 1: Specimen compliance as a function of relative crack depth, $\alpha$, according to Eq.(E) and Eq.(F).

[Figura 1: Flexibilidade da amostra como função da profundidade relativa da trinca, $\alpha$, de acordo com a Eq. (E) e Eq. (F).] 
modulus and a high $\gamma_{\text {wof }}$ to $\gamma_{\text {eff }}$ ratio, i.e., materials that display an rising R-curve behavior lend themselves more readily to stable crack growth. The minimum value for this ratio is 1 $\left(\gamma_{\text {wof }}=\gamma_{\text {eff }}\right)$ and occurs in absolutely brittle materials such as glass and single phase, fine-grained ceramics.

Still according to Eq.(G), it can be inferred that an important factor for test stability is machine compliance, $\lambda_{\mathrm{M}}$ : the more rigid the equipment (small $\lambda_{\mathrm{M}}$ ), including test support, frame and actuator, the less elastic energy is accumulated and transferred to the specimen during crack growth.

Even though this work was developed using chevronnotched specimens, the above analysis remains valid, requiring only geometric corrections in the stability equation, Eq.(G). The equation for the SENB geometry is presented here merely for didactic purposes.

\section{EXPERIMENTAL PROCEDURE}

The material selected for this study was a high-alumina, low-cement refractory concrete whose formulation, detailed in another report [7], followed Andreasen's model for particle size distribution, with the coefficient $q=0,21$. After mixing, which was done in a rheometer for concrete, developed by the authors' research group [8], 25 x 25 x $150 \mathrm{~mm}^{3}$ prismatic samples were cast under vibration. Curing was accomplished at room temperature, lasting $24 \mathrm{~h}$. This was followed by drying at $110{ }^{\circ} \mathrm{C}$ for another $24 \mathrm{~h}$. The material was then sintered at $1550{ }^{\circ} \mathrm{C}$ for $12 \mathrm{~h}$. The specimens more irregular sides were ground, after which it was notched with a 400 $\mu \mathrm{m}$ thick diamond disk in a chevron geometry conducive to stable crack growth.

The equipment used for the $\gamma_{\text {wof }}$ measurements, Netzsch's High Bending Strength Tester (HBST) 422, was originally developed to measure the hot modulus of rupture (HMOR). The slow crack propagation required to calculate $\gamma_{\text {wof }}$ was achieved with the aid of a device for maintaining a constant displacement rate, which was adjusted for $5 \mu \mathrm{m} /$ min. This device, illustrated schematically in Fig. 2, does not impose a constant bending arrow increase rate. The

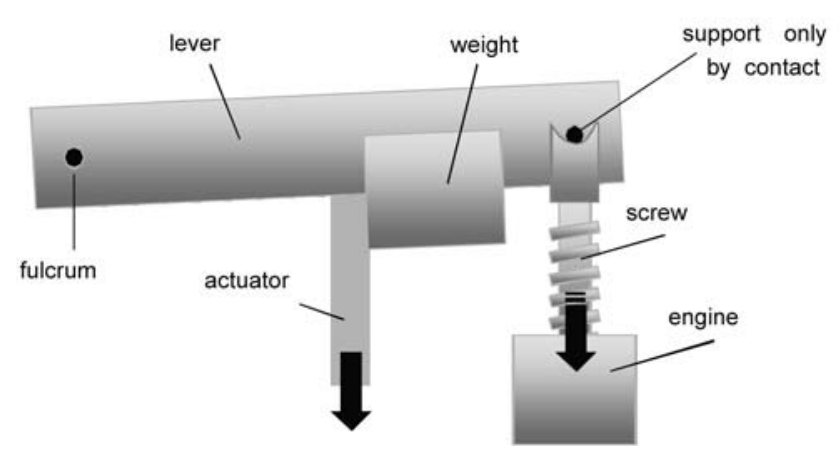

Figure 2: Details of the device for controlling the actuator's displacement rate during tests to determine the $\gamma_{\text {wof }}$.

[Figura 2: Detalhes do dispositivo para controlar o deslocamento do atuador durante os testes para a determinação de $\gamma_{\text {wof }}$ ] apparatus consists of a screw fixed to the body of the equipment, which supports a lever connected to a weight. The transfer of a load to the actuator therefore depends on the screw's vertical speed. In fact, the displacement rate, which remains constant, is therefore that of the screw. The displacement of the actuator relative to the ground depends on the elastic response of each part of the machine and the sample. Furthermore, if the load is insufficient to cause crack propagation, the lever connected to the actuator may detach from the support at the top end of the screw.

\section{EXPERIMENTAL RESULTS}

Fig. 3 depicts a load versus actuator displacement curve obtained from a 3-point bend test of the refractory concrete. The vertical speed of the screw was adjusted for $5 \mu \mathrm{m} / \mathrm{min}$. This figure also shows the load point displacement rate calculated from the LVDT data. The field highlighted in Fig. 3 corresponds to a region of semi-stable crack propagation, which was observed in all the samples. No data was recorded for this part of the P x d curve, since the instability led to a very rapid increase in displacement. The values of $\mathrm{v}_{\text {lvdt }}$ were also found to be much higher than the nominal $5 \mu \mathrm{m} / \mathrm{min}$, revealing an abrupt increase in the true speed of the load point. The energy of fracture, averaged from five samples of the same material and calculated by means of Eq.(A), was $98 \pm 14 \mathrm{~J} / \mathrm{m}^{2}$.

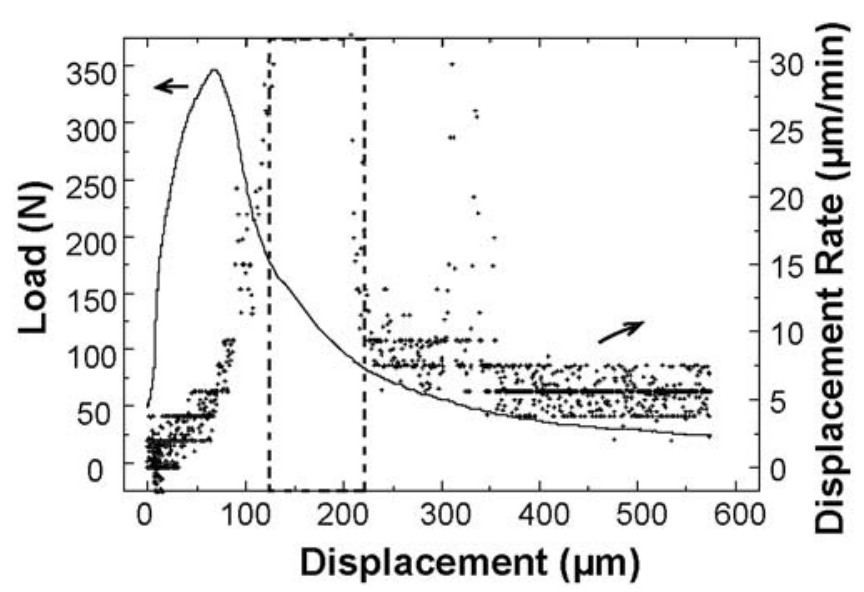

Figure 3: Curve of load $(\mathrm{P})$ and displacement rate $\left(\mathrm{v}_{\text {lvdt }}\right)$ as a function of displacement (d) for a 3-point bending test at a constant vertical speed of the screw (see Fig. 2).

[Figura 3: Curva de carga $(P)$ versus taxa de deslocamento $\left(v_{\text {lvd }}\right)$ como função do deslocamento (d) para um teste de flexão em 3 pontos sob velocidade vertical constante do parafuso (ver a Fig. 2).]

\section{DISCUSSION}

The equipment employed here is composed of several independent parts subjected to the same applied load P. The deformations occur as in a serial system, see Fig. 4, in which $\mathrm{x}_{1}, \mathrm{x}_{2}, \mathrm{x}_{\mathrm{S}}, \mathrm{x}_{\text {lvdt }}$ and $\mathrm{x}_{\text {total }}$ correspond to the absolute length of each part of the system. These variables relate, respectively, 
to the variations $\Delta \mathrm{x}_{1}, \Delta \mathrm{x}_{2}, \Delta \mathrm{x}_{\mathrm{S}}, \Delta \mathrm{x}_{\text {lvdt }}$ and $\Delta \mathrm{x}_{\text {total }}$ when the load $\mathrm{P}$ is applied. In this analysis, the silicon carbide bend fixture is considered sufficiently rigid to allow its deformation to be disregarded.

The variation in length detected by the extensometer, $\Delta \mathrm{x}_{\mathrm{lvdt}}$, was:

$$
\Delta \mathrm{X}_{\mathrm{lvdt}}=\Delta \mathrm{X}_{1}+\Delta \mathrm{X}_{\mathrm{S}}
$$

Although it consists of a long bar, the silicon carbide actuator is extremely stiff. Therefore, and considering the load level reached in the test (see Fig. 3), most of the measured displacement was due to the specimen's deflection upon bending.

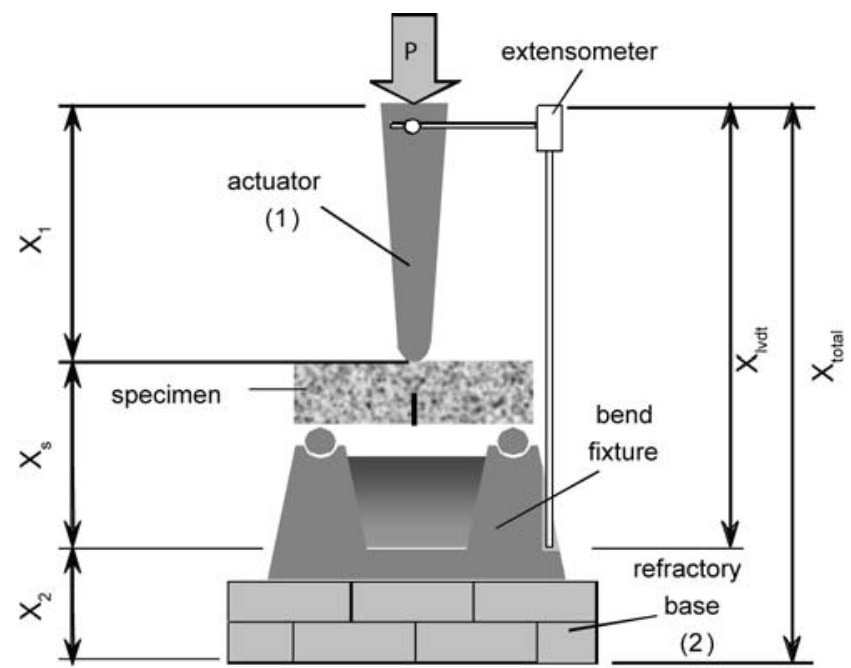

Figure 4: Drawing of the HBST 422 apparatus and its composite elements.

[Figura 4: Desenho esquemático do equipamento HBST 422 e seus principais elementos.]

The refractory base on which the system is mounted presents a high compliance. The variation in height from the LVDT's body to the ground, $\Delta \mathrm{x}_{\text {total }}$, is given by:

$$
\Delta \mathrm{X}_{\mathrm{total}}=\Delta \mathrm{X}_{\text {lvdt }}+\Delta \mathrm{X}_{2}
$$

The displacement rate of each part of the system is obtained by differentiating its displacement as a function of time:

$$
\begin{aligned}
& \mathrm{v}_{1}=\frac{\mathrm{dx}_{1}}{\mathrm{dt}}=\lambda_{1} \frac{\mathrm{dP}(\mathrm{t})}{\mathrm{dt}} \\
& \mathrm{v}_{\mathrm{S}}=\frac{\mathrm{dx}_{\mathrm{S}}}{\mathrm{dt}}=\lambda_{\mathrm{S}} \frac{\mathrm{dP}(\mathrm{t})}{\mathrm{dt}}
\end{aligned}
$$

and

$$
\mathrm{v}_{2}=\frac{\mathrm{dx}_{2}}{\mathrm{dt}}=\lambda_{2} \frac{\mathrm{dP}(\mathrm{t})}{\mathrm{dt}}
$$

where $\lambda_{1}$ and $\lambda_{2}$ are, respectively, the actuator and the refractory base compliances. According to Eq.(E), specimen compliance, $\lambda_{\mathrm{s}}$, varies only with crack propagation; therefore, $\lambda_{\mathrm{s}}, \lambda_{1}$ and $\lambda_{2}$ remain constant during elastic loading.

The load point displacement rate is calculated from the values recorded by the extensometer, $\mathrm{v}_{\text {lvdt }}$, which are given by:

$$
\mathrm{V}_{\text {lvdt }}=\mathrm{V}_{1}+\mathrm{V}_{\mathrm{S}}
$$

and the displacement rate at the top of the actuator, which is the reference for the LVDT, is given by:

$$
\mathrm{V}_{\text {total }}=\mathrm{V}_{\text {lvdt }}+\mathrm{V}_{2}
$$

Since all the parts' displacements are considered in $\mathrm{v}_{\text {total }}$, its value is theoretically equal to the displacement rate established by the operator and controlled by the screw movement on the device for a constant displacement rate.

During elastic loading, all the parts of the system are compressed according to their own compliances, and $\mathrm{v}_{\text {total }}$ is shared by them, as illustrated schematically in Fig. 5. In this figure, the curve of $\mathrm{v}_{\text {lvdt }}$ is the time-derivative of the curve $\left(\Delta \mathrm{x}_{1}+\Delta \mathrm{x}_{\mathrm{S}}\right)$. With the beginning of crack propagation, the
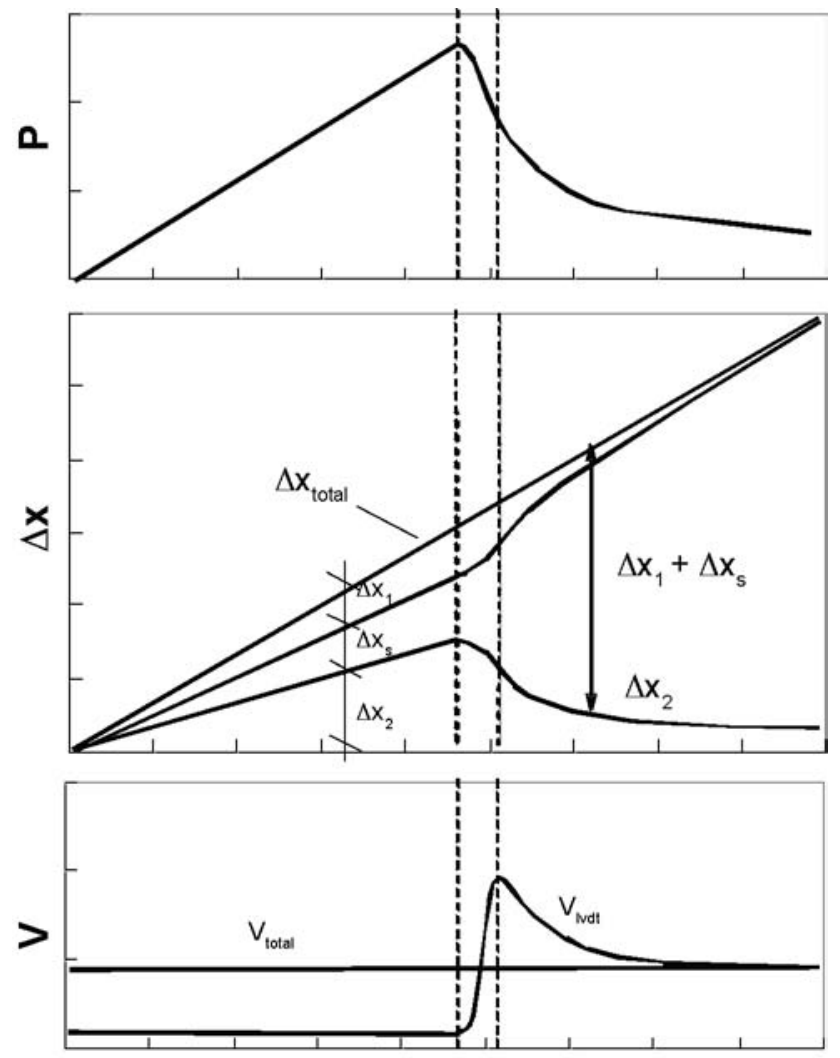

time

Figure 5: Load, P, displacement, $\Delta \mathrm{x}$, and displacement rate of the system's parts, $\mathrm{v}$, as a function of time during a test under controlled displacement rate.

[Figura 5: Carga, $P$, deslocamento, $\Delta x$, e taxa de deslocamento das partes do sistema, $v$, como função do tempo ao longo de um teste sob controle de taxa de deslocamento.] 
actuator's upper point moves at a constant rate equal to $\mathrm{v}_{\text {total }}$. The specimen, in turn, begins to deflect, relieving the load and gradually passing it back to the screw. Since the system is restricted by $\mathrm{v}_{\text {total }}$, which remains constant throughout the test, parts 1 and 2 return progressively to their original sizes, thereby further bending the specimen and leading to an increase of $\mathrm{v}_{\mathrm{S}}$, which, in turn, increases $\mathrm{v}_{\text {lvdt }}$.

An increase in $\mathrm{v}_{\text {lvdt }}$ may be perceived in the tests on refractory concrete, as demonstrated by the displacement rate results shown in Fig. 3. This rate increases considerably after the peak load, favoring the occurrence of instabilities in the crack's propagation. The shape of the experimental curve agrees with that of $\mathrm{v}_{\text {lvdt }}$ presented in Fig. 5.

Soon after the peak shown in Fig. 3 was reached, the measured displacement rate returned to the adjusted value of $\mathrm{v}_{\text {total }}$, indicating the occurrence of semi-stable crack propagation throughout the still intact portion of the specimen and concluding the fracture process. The residual load was due only to the roughness of the two fracture surfaces [9].

The testing machine greatly enhances the possibility of attaining the energy of fracture, since stable crack propagation is a requirement in this case. The details of the mechanics of this test enable researchers to obtain more significant results regarding the mechanical behavior of brittle materials, which, in turn, facilitates the development of materials that perform better under severe mechanical conditions.

\section{SUMMARY}

The present study corroborates the importance of machine stiffness in attaining stable crack propagation in three-point bending tests controlled by actuator displacement. The low stiffness of some parts of the machine leads to the absorption of elastic energy, which is gradually released during the crack propagation, increasing the speed of propagation. This fact may cause instabilities which, though not completely hindering the accomplishment of the test, nevertheless confer a significant level of experimental bias on the data.

\section{ACKNOWLEDGEMENTS}

The authors wish to thank the Brazilian research-funding agencies FAPESP and CNPq for their financial support, and ALCOA - Brazil for providing the raw materials used in this work.

\section{NOMENCLATURE}

$\begin{array}{ll}\text { A } & \text { projected area of a fracture surface }\left(\mathrm{m}^{2}\right) \\ \text { b } & \text { specimen width (m) } \\ \text { c } & \text { crack length (m) } \\ \text { d } & \text { displacement (m) } \\ \text { E } & \text { Young’s Modulus (Pa) } \\ \text { G } & \text { shear modulus (Pa) } \\ \text { h } & \text { specimen height (m) } \\ \text { L } & \text { lower span (m) }\end{array}$

P $\quad \operatorname{load}(\mathrm{N})$

q Andreasen's distribution coefficient

$\mathrm{t}$ time (s)

$\mathrm{Y}$ geometric correction of $\mathrm{K}_{\mathrm{IC}}$

$\alpha$ relative crack length

$\Delta \mathrm{x}_{1}$ length variation of the actuator length (m)

$\Delta \mathrm{x}_{2}$ height variation of the refractory base height (m)

$\Delta \mathrm{x}_{\text {lvdt }}$ length variation measured by the extensometer (m)

$\Delta \mathrm{x}_{\mathrm{S}}$ deflection of the specimen (m)

$\Delta \mathrm{x}_{\text {total }}$ overall system length variation (m)

$\gamma_{\text {eff }}$ effective fracture energy $\left(\mathrm{J} / \mathrm{m}^{2}\right)$

$\gamma_{\text {wof }}$ energy of fracture $\left(\mathrm{J} / \mathrm{m}^{2}\right)$

$\lambda_{\mathrm{M}}$ machine compliance $(\mathrm{m} / \mathrm{N})$

$\lambda_{\mathrm{s}} \quad$ specimen compliance $(\mathrm{m} / \mathrm{N})$

$v$ Poisson's ratio

$\mathrm{K}_{\mathrm{IC}}$ fracture toughness $\left(\mathrm{Nm}^{1 / 2}\right)$

$U_{k} \quad$ kinetic energy of the crack front (J)

$\mathrm{U}_{\mathrm{M}} \quad$ elastic energy stored in the testing machine (J)

$\mathrm{U}_{\mathrm{S}} \quad$ elastic energy stored in the specimen (J)

$\mathrm{U}_{\mathrm{T}} \quad$ overall elastic energy stored in the system (J)

$\mathrm{x}_{1}$ absolute length of the actuator (m)

$\mathrm{x}_{2}$ absolute height of the refractory base (m)

$\mathrm{x}_{\text {lvdt }}$ absolute length detected by the extensometer (m)

$\mathrm{x}_{\mathrm{S}} \quad$ absolute position of the load point (m)

$\mathrm{x}_{\text {total }}$ absolute length (or height) of the entire system

$\mathrm{v}_{1}$ rate of length variation for the actuator $(\mathrm{m} / \mathrm{s})$

$v_{2}$ rate of height variation for the refractory base $(\mathrm{m} / \mathrm{s})$

$\mathrm{v}_{\text {lvdt }}$ rate of length variation detected by the extensometer $(\mathrm{m} / \mathrm{s})$

$\mathrm{v}_{\mathrm{S}}$ rate of deflection of the specimen $(\mathrm{m} / \mathrm{s})$

$\mathrm{v}_{\text {total }}$ rate of length (or height) variation considering the deformation of the entire system $(\mathrm{m} / \mathrm{s})$

$\mathrm{W}_{\mathrm{fs}}$ overall work developed by the machine (J)

\section{REFERENCES}

[1] R. C. Bradt, "Fracture measurements of refractories: past, present and future”, Am. Ceram. Soc. Bull. 67, 7 (1988) 1176-1178.

[2] Y. T. Chien, Y. C. Ko, "High-temperature fracture energy and thermal-stress resistance parameters of bauxite brick", Am. Ceram. Soc. Bull. 64, 7 (1985) 1017-1020.

[3] F. Simonin, C. Olagnon, S. Maximilien, G. Fantozzi, L. A. Dias, R. Torrecillas, "Thermomechanical behavior of high-alumina refractory with synthetic spinel additions", J. Am. Ceram. Soc. 83, 10 (2000) 2481-2490.

[4] C. M. Peret, J. A. Rodrigues, "Stable fracture of ceramics under 3-point bending controlled by CMOD" (In Portuguese), Proc. $44^{\text {th }}$ Brazilian Ceramic Congress, ABC, S. Pedro, SP, Brazil, cdrom (2000) 11 p.

[5] J. Nakayama, H. Abe, R. C. Bradt, "Crack stability in the work-of-fracture test: refractory applications”, J. Am. Ceram. Soc. 64, 11 (1981) 671-675.

[6] M. Sakai, K. Yamasaki, "Numerical fracture-analysis of chevron-notched specimens. 2. Stability condition for crack- 
growth”, J. Am. Ceram. Soc. 66, 5 (1983) 376-379.

[7] C. M. Peret, "High-temperature work-of-fracture and the thermal shock of advanced refractory castables", M.Sc. Diss., Federal University of S. Carlos, S. Carlos, SP, Brazil (2002) 119 p (in Portuguese).

[8] R. G. Pileggi, V. C. Pandolfelli, A. E. Paiva, J. Gallo,
"Novel rheometer for refractory castables", Am. Ceram. Soc. Bull. 79, 1 (2000) 54-58.

[9] M. F. A. Magon, J. A. Rodrigues, V. C. Pandolfelli, "Characterization of R-curve behavior of MgO-C refractories”, Proc. 39 $9^{\text {th }}$ Brazilian Ceramic Congress, Águas de Lindóia, SP, Brazil (1995) 478-482 (in Portuguese). (Rec. 08/01/2008, Ac. 08/02/2008) 